\title{
Pengaruh Asimetri Informasi, Ukuran Perusahaan, Leverage dan Profitabilitas pada Manajemen Laba
}

\author{
Ni Putu Tia Rahma Yanti \\ Putu Ery Setiawan ${ }^{2}$ \\ ${ }^{1,2}$ Fakultas Ekonomi dan Bisnis Universitas Udayana (Unud), Bali, Indonesia \\ e-mail: gektya.24@gmail.com
}

\begin{abstract}
ABSTRAK
Manajemen laba muncul sebagai dampak persoalan keagenan dimana terjadi ketidakselarasan kepentingan antar pemilik dan manajemen. Penelitian ini bertujuan untuk mengetahui apakah asimetri informasi, ukuran perusahaan, leverage, dan profitabilitas berpengaruh pada manajemen laba.Penelitian ini dilakukan pada Perusahaan Manufaktur yang terdaftar di Bursa Efek Indonesia periode 2014-2016. Jumlah sampel dalam penelitian ini sebanyak 33 perusahaan manufaktur.Penelitian ini menggunakan pendekatan nonprobabilitas sampling dengan metode purposive sampling.Teknik analisis yang digunakan yaitu analisia regresi linear berganda.Berdasarkan hasil analisis penelitian dapat diketahui bahwa variabel asimetri informasi tidak berpengaruh pada manajemen laba. Ukuran perusahaan yang diukur dengan log aktiva berpengaruh negatif signifikan pada manajemen laba. Sedangkan leverage dan profitabilitas berpengaruh positif dan signifikan pada manajemen laba.
\end{abstract}

Kata Kunci: Manajemen laba, asimetri informasi, ukuran perusahaan, leverage, dan profitabilitas.

\section{ABSTRACT}

Earnings management arises as an effect of agency problems where there is an inconsistency in interests between owners and management. This study aims to determine whether information asymmetry, company size, leverage, and profitability influence earnings management. This research was conducted at Manufacturing Companies listed on the Indonesia Stock Exchange for the 2014-2016 period. The number of samples in this study were 33 manufacturing companies. This study uses a nonprobability sampling approach with a purposive sampling method. The analysis technique used is multiple linear regression analysis. Based on the results of the research analysis it can be seen that the information asymmetry variable has no effect on earnings management. Firm size measured by asset log has a significant negative effect on earnings management. While leverage and profitability have a positive and significant effect on earnings management.

Keywords: Earnings management, information asymmetry, company size, leverage, and profitability.

\section{PENDAHULUAN}

Informasi laba pada umumnya merupakan faktor penting dalam mengukur kinerja manajemen, selain itu informasi laba tersebut membantu pemilik dan pihak lain yang berkepentingan terhadap perusahaan melakukan penaksiran atas earning power perusahaan di masa yang akan datang. Oleh karena itu perubahan informasi atas laba bersih suatu perusahaan melalui berbagai cara akan 
memberikan dampak yang cukup berpengaruh pada tindak lanjut para pengguna informasi laba tersebut, salah satunya dengan cara melakukan manajemen laba (earning mangement) (Nufus, 2009).

Manajemen laba pada umumnya didasarkan pada berbagai alasan baik untuk memuaskan kepentingan pemilik perusahaan seperti menaikan nilai perusahaan sehingga akan muncul anggapan bahwa perusahaan tersebut memiliki prospek yang bagus untuk berinvestasi karena perusahaan memiliki risiko yang rendah, menaikkan harga saham perusahaan, dan perilaku oportunistik manajer seperti untuk mendapatkan kompensasi, dan mempertahankan jabatannya (Juniarti dan Corolina, 2005). Akan tetapi dengan adanya manajemen laba, menurut Kim et.al (2003) semua perusahaan dalam berbagai ukuran terbukti senantiasa melaporkan positive earnings, untuk menghindari earnings losses atau earning decreases.Perilaku manajer tersebut pada waktunya akan cenderung berdampak pada adanya praktik manipulasi (Handayani dan Rachadi, 2009).

Manajemen laba muncul sebagai dampak persoalan keagenan dimana terjadi ketidakselarasan kepentingan antar pemilik dan manajemen (Beneish, 2001). Salah satu mekanisme yang digunakan untuk mencoba menurunkan konflik yang disebabkan oleh pemisahan kepemilikan dan kontrol diantara kedua belah pihak adalah dengan menawarkan manajer untuk berpartisipasi dalam program opsi saham yang dikenal sebagai kompensasi berbasis saham (stockbased compensation). Pemberian kompensasi untuk manajer akan mengakibatkan peningkatan kepemilikan manajerial (Prempanichnukul dan 
Krittaya,2012).

Informasi dalam suatu perusahaan merupakan suatu hal yang sangat penting, sehingga dibutuhkan oleh pemilik atau principal.Oleh sebab itu pihak manajemen atau agent harus menyampaikan informasi tersebut secara transparan.Tetapi sering terjadi dimana pihak manajemen (agent) dalam menyampaikan informasi kepada principal tidak sesuai dengan keadaan yang sebenarnya dan cenderung memanipulasi informasi tersebut.Sehingga informasi yang diperoleh principal dapat bersifat menyesatkan.Hal ini dilakukan oleh agent karena Principal memberikan kewenangan dan otoritas kepada agent untuk menjalankan perusahaan demi kepentingan principal.Sehingga manajer selaku agent mengetahui informasi internal lebih banyak mengenai perusahaan dibandingkan dengan principal (Rahmawati, dkk 2006). Manajer beranggapan bahwa apabila dia meningkatkan kinerjanya dengan cara melakukan tindakan tersebut maka principal akan memberikan bonus kepada agent. Informasi yang luas mengenai kondisi perusahaan yang dimiliki oleh agent dan informasi minim yang diterima oleh principal disebut asimetri informasi.Sehingga memberikan kesempatan kepada agent untuk melakukan tindakan praktik manajemen laba.

Beberapa penelitian telah dilakukan mengenai hubungan asimetri informasi dengan praktik manajemen laba. Salah satunya penelitian Richardson (1998) menyatakan terdapat hubungan positif antara asimetri informasi dengan manajemen laba.Penelitian sejalan juga ditemukan oleh Rahmawati, dkk (2006) dan Muliati (2011). Jadi ketika asimetri informasi tinggi, stakeholderstidak 
Ni Putu Tia Rahma Yanti dan Putu Ery Setiawan. Pengaruh ...

memiliki sumber daya yang cukup, insentif atau akses informasi yang relevan untuk memonitor tindakan manajemen. Hal ini akan memberikan peluang kepada manajer untuk melakukan pengelolaan laba. Sebaliknya penelitian yang dilakukan oleh Firdaus (2013) yang menyatakan bahwa asimetri informasi tidak berpengaruh pada manajemen laba.Siregar (2006) pada penelitiannya menemukan hasil bahwa asimetri informasi tidak berpengaruh terhadap manajemen laba.

Perusahaan yang berukuran besar memiliki basis pemegang kepentingan yang lebih luas, sehingga berbagai kebijakan perusahaan besar akan berdampak lebih besar terhadap kepentingan public dibandingkan dengan perusahaan kecil. Bagi investor, kebijakan perusahaan akan berimplikasi terhadap prospek cash flow dimasa yang akan datang.

Nuryaman (2008) dalam Dewi (2010) menemukan bahwa ukuran perusahaan berpengaruh negatif terhadap mnjemen laba. Moses (1997) menyatakan perusahaan berukuran besar akan memiliki dorongan yang lebih besar untuk melakukan praktek manajemen laba dibandingkan dengan perusahaan kecil, karena memiliki biaya politik lebih besar, selain itu perusahaan besar memiliki aktivitas operasional yang lebih kompleks dibandingkan perusahaan kecil, sehingga dapat memungkinkan untuk melakukan praktek manajemen laba.

Rasio yang digunakan untuk mengetahui seberapa besar perusahaan dibiayai oleh hutang merupakan definisi dari leverage (Riyanto, 1995:331). Rasio ini menggambarkan hubungan antara hutang perusahaan terhadap modal maupun asset. Menurut (VAN Horne, 1997)financial Leverage merupakan 
penggunaan sumber dana yang memiliki beban tetap, dengan harapan akan memberikan tambahan keuntungan yang lebih besar dari pada beban tetap, sehingga keuntungan pemegang saham bertambah. Penelitian yang dilakukan oleh Saptantinah (2007), Othman dan Zhegal (2006), Rice dan Agustina (2012), menemukan hubungan signifikan antara leverage dan manajemen laba. Zhou dan Lobo (2001), Veronica dan Bachtiar (2003) menemukan bahwa leverage berpengaruh negatif terhadap manajemen laba.

Profitabilitas menggambarkan kemampuan perusahaan dalam pengelolaan asset untuk menghasilkan laba.Profitabilitas menunjukkan kemampuan perusahaan dalam menghasilkan laba selama satu periode waktu tertentu.Pada umumnya nilai profitabilitas suatu perusahaan dapat digunakan sebagai indikator untuk mengukur kinerja suatu perusahaan.Chen $\mathrm{Ju}$ dan $\mathrm{Yu}$ Chen (2011) menyatakan bahwa semakin tinggi profitabilitas suatu perusahaan maka kinerja dan kemampuan perusahaan dalam menghasilkan keuntungan juga meningkat.Penelitian yang dilakukan oleh Setiyanto dan Raharja (2012) menemukan bahwa profitabilitas berpengaruh negatif terhadap manajemen laba.Wibisana dan Ratnaningsih (2014) menyatakan bahwa tingkat profitabilitas berpengaruh terhadap tindakan perataan laba yang dilakukan perusahaan, dimana tindakan perataan laba merupakan salah satu metode yang dilakukan perusahaan dalam manajemen laba.

Penelitian ini dilakukan di perusahaan manufaktur yang terdaftar di bursa efek Indonesia. Alasan peneliti memilih perusahaan manufaktur, karena perusahaan manufaktur merupakan taraf perusahaan yang besar dan sangat 
Ni Putu Tia Rahma Yanti dan Putu Ery Setiawan. Pengaruh ...

berpengaruh dalam perkembangan perekonomian Negara dan komponen laba dalam laporan keuangan perusahaan manufaktur disajikan secara detail. Persaingan perusahaan manufaktur juga semakin meningkat, dengan demikian kemungkinan untuk melakukan aktivitas manajemen laba sangat besar.

Keberadaan asimetri informasi dianggap sebagai penyebab manajemen laba, Richardson (1998) berpendapat bahwa terdapat hubungan yang sistematis antara asimetri informasi dengan tingkat manajemen laba. Adanya asimetri informasi akan mendorong manajer untuk menyajikan informasi yang tidak sebenarnya terutama jika informasi tersebut berkaitan dengan pengukuran kinerja manajer. Fleksibelitas manajemen untuk melakukan manajemen laba dapat dikurangi dengan menyediakan inforasi yang lebih berkualitas bagi pihak luar. Kualitas laporan keuangan akan mencerminkan tingkat manajemen laba.

Asimetri informasi dapat mempengaruhi praktik manajemen laba yang dilakukan oleh manajer, seperti yang dikemukakan oleh penelitian Richardson (1998). Ketika asimetri informasi tinggi, stakeholder tidak memiliki sumber daya yang cukup atas informasi yang relevan dalam memonitor tindakan manajer sehingga akan memunculkan praktik manajemen laba. Akibatnya asimetri informasi ini akan mendororng manajer untuk tidak menyajikan informasi selengkapnya. Jika informasi tersebut berkaitan dengan pengukuran kinerja manajer.

Beberapa peneliti telah menemukan bahwa asimetri informasi dapat mempengaruhi manajemen laba.Teori keagenan (Agency Theory) mengimplikasikan adanya asimetri informasi antara manajer sebagai agen dan 
pemilik (dalam hal ini adalah pemegang saham) sebagai principal.Schiff \& Lewin (1970) menyatakan bahwa asimetri informasi muncul ketika manajer lebih mengetahui informasi internal dan prospek perusahaan di masa yang akan datangdibandingkan pemegang saham dan stakeholoder lainnya. Jika dikaitkan dengan peningkatan nilai perusahaan, ketika terdapat asimetri informasi, manajer dapat memberikan sinyal mengenai kondisi perusahaan kepada investor guna memaksimisasi nilai perusahaan.Sinyal yang diberikan dapat dilakukan melalui pengungkapan (disclosure) informasi akuntansi.

Cristie \& Zimmerman (1994) membuktikan bahwa perusahaan yang melakukan take over cenderung memilih metode depresiasi dan metode pencatatan persediaan, yang dapat meningkatkan laba akuntansi. Berdasarkan penelitian tersebut dapat disimpulkan bahwa terdapat sikap opportunistic manajemen dalam kasus ambil alih perusahaan, sekalipun alasan utama pemilihan metode akuntansi didasarkan pada pertimbangan efisiensi atau pertimbangan memaksimalkan nilai perusahaan.Sesuai dengan penelitian Rahmawati (2006) bahwa asimetri informasi mempunyai pengaruh signifikan positif terhadap manajemen laba, begitu juga dengan penelitian yang dilakukan oleh Desmiyawati (2009) dan Muliati (2011).Sebaliknya penelitian yang dilakukan oleh Firdaus (2013) yang menyatakan bahwa asimetri informasi tidak berpengaruh pada manajemen laba.Siregar (2006) pada penelitiannya menemukan hasil bahwa asimetri informasi tidak berpengaruh terhadap manajemen laba. Berdasarkan uraian diatas maka hipotesis yang diajukan dalam penelitian ini adalah : $\mathrm{H}_{1}$ : Asimetri informasi berpengaruh positif pada manajemen laba. 
Perusahaan yang lebih besar umumnya akan mendapatkan lebih banyak perhatian dari pihak eksternal, seperti investor, analis, maupun pemerintah. Oleh sebab itu perusahaan akan menghindari fluktuasi laba yang terlalu drastis, sebab kenaikan laba yang drastis akan menyebabkan pertambahan kewajiban seperti pajak. Perusahaan besar akan cenderung berusaha untuk melaporkan perolehan laba yang stabil setiap tahunnya.

Siregar dan Utama (2005) melakukan penelitian mengenai pengaruh ukuran perusahaan terhadap manajemen laba dan menyatakan bahwa ukuran perusahaan berpengaruh signifikan terhadap manajemen laba. Hasil penelitian terdahulu Nuryaman (2008) dalam Dewi (2014) dan Chtourou et al.(2001) menemukan bahwa ukuran perusahaan berpengaruh negatif terhadap manajemen laba. Jao dan Pagalung (2011), Prambudi dan Sumantri (2014), Makaombohe dkk (2014), serta Wibisana dan Ratnaningsih (2014) menyatakan bahwa ukuran perusahaan berpengaruh signifikan terhadap manajemenlaba.

Ukuran perusahaan memiliki hubungan positif dengan manajemen laba, karena perusahaan besar memiliki aktivitas operasional yang lebih kompleks dibandingkan perusahaan kecil, sehingga lebih memungkinkan untuk melakukan manajemen laba.Moses (1997) mengemukakan bahwa perusahaan-perusahaam yang lebih besar memiliki dorongan yang lebih besar untuk melakukan perataan laba (salah satu bentuk manajemen laba) dibandingkan dengan perusahaan kecil, karena memiliki biaya politik lebih besar.Biaya politik muncul karena profitabilitas perusahaan yang tinggi dapat menarik perhatian media dan konsumen. Berdasarkan keterkaitan yang dijelaskan diatas, maka hipotesis yang 
diajukan adalah:

$\mathrm{H}_{2}$ : Ukuran perusahaan berpengaruh positif pada manajemen laba.

Tingkat leverage merupakan salah satu hal yang dapat memotivasi manajemen dalam penerapan manajemen laba. Perusahaan yang memiliki tingkat leverage yang tinggi menggambarkan bahwa liabilitas yang dimiliki perusahaan lebih besar dibandingkan dengan asset yang dimiliki perusahaan, hal ini mengakibatkan risiko dan tekanan yang besar pada perusahaan. Semakin tinggi tingkat rasio leverage suatu perusahaan akan berdampak pada semakin tinggi pula resiko yg akan dihadapi perusahaan tersebut. Investor akan lebih memilih perusahaan yang memiliki tingkat leverage yang lebih rendah.

Perusahaan yang memiliki rasio leverage yang tinggi berarti memiliki proporsi utang yang lebih besar dibandingkan dengan proporsi aktiva yang dimiliki sehingga akan cenderung melakukan manipulasi dalam bentuk manajemen laba untuk menghindari perjanjian utang (Saptantinah, 2005:7).

Shanti dan Yudhanti (2007) dalam Purwanti (2012) juga berpendapat bahwa perusahaan yang memiliki leverage tinggi akibat besarnya liabilitas dibandingkan aktiva yang dimiliki perusahaan, diduga melakukan manajemen laba karena perusahaan terancam default, yaitu tidak dapat memenuhi kewajiban membayar liabilitas pada waktunya. Penelitian yang dilakukan oleh Dewi Saptantinah (2005), Othman dan Zhegal (2006), Rice dan Agustina (2012), menemukan hubungan signifikan antara leverage dan manajemen laba. Lobo dan Zhou (2001) dalam Veronica dan Bachtiar (2003) menemukan bahwa leverage berpengaruh negatif terhadap manajemen laba. Berdasarkan keterkaitan 
Ni Putu Tia Rahma Yanti dan Putu Ery Setiawan. Pengaruh ...

yang dijelaskan diatas, maka hipotesis yang diajukan adalah:

$\mathrm{H}_{3}$ : Leverage berpengaruh positif pada manajemen laba.

Profitabilitas adalah tingkat keuntungan bersih yang berhasil diperoleh perusahaan dalam menjalankan operasionalnya.Dalam kaitannya dengan manajemen laba (earning management), profitabilitas dapat mempegaruhi manajer untuk melakukan manajemen laba. Karena jika profitabilitas yang didapat perusahaan rendah, umumnya manajer akan melakukan tindakan manajemen laba untuk menyelamatkan kinerjanya di mata pemilik. Hal ini berkaitan erat dengan usaha manajer untuk menampilkan performa terbaik dari perusahaan yang dipimpinnya.Archibalt dalam Herni dan Yulius Kurnia Susanto (2008) menjelaskan bahwa perusahaan yang memiliki profitabilitas rendah cenderung melakukanperataan laba.Perataan laba merupakan salah satu bentuk dari manajemen laba. Manajer cenderung melakukan aktivitas tersebut karena dengan laba yang rendah atau bahkan menderita kerugian, akan memperburuk kinerja manajer di mata pemilik dan nantinya akan memperburuk citra perusahaan di mata public.

Profitabilitas menggambarkan kinerja yang dihasilkan oleh suatu perusahaan pada suatu periode waktu tertentu. Salah satu rasio analisis yang digunakan untuk menggambarkan profitabilitas perusahaan adalah Return On Assets (ROA). ROA menunjukkan kemampuan perusahaan menghasilkan laba dari asset yang dimiliki perusahaan. Para investor akan menggunakan rasio ROA sebagai salah satu indikator dalam pengambilan keputusan dalam hal investasi. Semakin tinggi tingkat profitabilitas yang dilaporkan oleh perusahaan, maka 
semakin tinggi pula harapan dari pihak-pihak berkepentingan seperti investor, pemerintah, dan lainnya atas tingkat pengembalian dan kompensasi yang diharapkan dari keuntungan yang diperoleh perusahaan.

Laba yang terlalu tinggi akan meningkatkan pajak yang harus dibayar, sedangkan pelaporan laba yang terlalu rendah akan berdampak pada tampilan kinerja manajemen yang tidak maksimal. Oleh karena itu, tinggi rendahnya profitabilitas yang dihasilkan berkaitan dengan tindakan manajemen laba dengan tujuan pelaporan tingkat profitabilitas yang berada pada tahap aman.

Wibisana dan Ratnaningsih (2014) menyatakan bahwa profitabilitas berpengaruh positif terhadap praktik perataan laba yang merupakan salah satu cara dalam praktik manajemen laba. Artinya, semakin besar profitabilitas suatu perusahaan, semakin besar pula kemungkinan perusahaan menurunkan atau meratakan laba untuk satu tahun kedepan. Hasil yang sama juga diperoleh dari penelitian yang dilakukan oleh Dewi dan Sujana(2014). Penelitian yang dilakukan oleh Setiyanto dan Raharja (2012) menemukan bahwa profitabilitas berpengaruh negatif terhadap manajemen laba. Berdasarkan keterkaitan diatas, maka hipotesis yang diajukan adalah:

$\mathrm{H}_{4}$ : Profitabilitas berpengaruh positif pada manajemen laba.

\section{METODE PENELITIAN}

Penelitian ini dilakukan pada perusahaan manufaktur yang terdaftar di Bursa Efek Indonesia (BEI) periode 2014-2016, dengan mengunduh annual report yang diakses melalui situs www.idx.co.id. Variabel terikat (Y) dalam penelitian ini 
adalah manajemen laba.Variabel bebas (X) dalam penelitian ini adalah asimetri informasi, ukuran perusahaan, leverage, dan profitabilitas.

Manajemen laba dalam penelitian ini diproksikan dengan akrual diskresioner menggunakan Model Jones Modifikasi (1991). Persamaannya sebagai berikut :

Menghitung total akrual

$$
\mathrm{TAC}_{\mathrm{it}}=\text { NIit }- \text { CFOit }
$$

Menentukan nilai nondiscretionary akrual

$$
N D A_{c c i t}=\alpha_{1}\left(\frac{1}{\text { TAct }_{i t-1}}\right)+\beta_{1}\left\{\frac{\left(\Delta \operatorname{Rev}_{i t}-\Delta \operatorname{Rec}_{i t}\right)}{\text { TAct }_{i t-1}}\right\}+\beta_{2}\left(\frac{P P E_{i t}}{T_{A c t}}\right)+\varepsilon \ldots .
$$

Menghitung nilai discretionary akrual

$$
\mathrm{DTAC}_{\mathrm{it}}=\left(\frac{T A C_{i t}}{T A_{i t-1}}\right)-N D T A C_{i t}
$$

Keterangan :

$\mathrm{TAC}_{\mathrm{it}}=$ Total akrual perusahaan $\mathrm{i}$ pada periode $\mathrm{t}$

NIit $\quad=$ laba bersih perusahaan i pada periode $\mathrm{t}$

CFOit $=$ Aliran arus kas operasi perusahaan i pada periode $\mathrm{t}$

Tact $_{\mathrm{it}^{-1}}=$ Total aktiva perusahaan $\mathrm{i}$ pada periode $\mathrm{t}$

$\triangle \mathrm{REV}_{\mathrm{it}} \quad=$ Perubahan penjualan perusahaan $\mathrm{i}$ pada periode $\mathrm{t}$

$\triangle \mathrm{REC}_{\mathrm{it}}=$ Perubahan piutang perusahaan i pada periode $\mathrm{t}$

$\mathrm{PPE}_{\mathrm{it}} \quad=$ Aktiva tetap perusahaan i pada periode $\mathrm{t}$

NDTAC $_{i t}=$ Non Discretionary accrual perusahaan i pada periode $\mathrm{t}$

DTAC $_{\text {it }}=$ Discretionary accrual perusahaan i pada periode $\mathrm{t}$

$\varepsilon \quad=$ Error term

Asimetri informasi diproksikan dengan menggunakan Relative Bid - ask Spread, dimana asimetri informasi dilihat dari selisih harga saat ask dengan harga bid saham perusahaan atau selisih harga jual dan harga beli saham perusahaan selama satu tahun(Healy, 1999) dalam (Mayanda, 2008)

Spread $=\frac{\text { ask price-bid price }}{(\text { ask price }+ \text { bid price }) / 2} \times 100$

Keterangan :

Spread = Selisih harga ask (jual) dengan harga bid (beli) saham perusahaan 
Ask price = harga ask (jual) tertinggi saham perusahaan

Bid price = harga bid (beli) terendah saham perusahaan

Dalam penelitian ini pengukuran ukuran perusahaan diproksikan dengan menggunakan total aktiva yang dimiliki perusahaan, yang diperoleh dari Neraca Perusahaan (Lindira, 2014).

Ukuran perusahaan $=\operatorname{Ln}($ total aktiva)

Leverage diukur dengan menggunakan rasio total utang terhadap total asset (Welvin dan Herawaty, 2004).

Leverage $=\frac{\text { Totalutang }}{\text { Aktiva }}$

Keterangan :

Leverage $=$ Rasio utang terhadap aktiva

Utang = total utang

Aktiva $\quad=$ total aktiva

Penelitian ini menggunakan ROA sebagai pengukuran untuk rasio profitabilitas dengan menggunakanrumus:

$$
R O A=\frac{\text { Laba bersih }}{\text { Total asset }} \times 100
$$

Populasi dalam penelitian ini adalah perusahaan manufaktur yang terdaftar di Bursa Efek Indonesia dari tahun 2014-2016 yang dapat diakses melalui www.idx.co.id.Sampel yang digunakan dalam penelitian ini meliputi perusahaan manufaktur yang terdaftar di Bursa Efek Indonesia (BEI) yang mewakili sifat-sifat populasi dengan metode purposive sampling.

Alat analisis yang digunakan adalah teknik analisis regresi berganda.persamaan regresi linier berganda penelitian ini menggunakan model sebagai berikut :

$$
\mathrm{Y}=\alpha+\beta_{1} \mathrm{X}_{1}+\beta_{2} \mathrm{X}_{2}+\beta_{3} \mathrm{X}_{3}+\beta_{4} \mathrm{X}_{4}+\varepsilon
$$


Keterangan :

$\begin{array}{ll}\mathrm{Y} & =\text { Manajemen Laba } \\ \alpha & =\text { Nilai konstanta } \\ \beta_{1} \beta_{2} \beta_{3} \beta_{4} & =\text { Koefisien regresi variabel independen } \\ \mathrm{X}_{1} & =\text { Asimetri informasi } \\ \mathrm{X}_{2} & =\text { Ukuran perusahaan } \\ \mathrm{X}_{3} & =\text { Leverage } \\ \mathrm{X}_{4} & =\text { Profitabilitas } \\ \varepsilon & =\text { Standar eror }\end{array}$

\section{HASIL DAN PEMBAHASAN}

Berdasarkan hasil analisis statistik deskriptif terhadap asimetri informasi (X1) maka didapatkan hasil bahwa nilai minimum sebesar $-5245,3709$ serta nilai maksimum sebesar 14633,6663 dan nilai mean sebesar 267,103061 sedangkan nilai standar deviasi sebesar 1810,7185223 .

Tabel 1.

Hasil Uji Statistik Deskriptif

\begin{tabular}{lrrrrr}
\hline & N & \multicolumn{1}{c}{ Minimum } & \multicolumn{1}{c}{ Maximum } & \multicolumn{1}{c}{ Mean } & \multicolumn{1}{c}{ Std. Deviation } \\
\hline X1 & 99 & $-5245,3709$ & 14633,6663 & 267,103061 & 1810,7185223 \\
X2 & 99 & 4,6029 & 7,6457 & 6,187331 & 0,7143145 \\
X3 & 99 & 4,1224 & 106,8458 & 42,570372 & 25,1292393 \\
X4 & 99 & $-15,8412$ & 334,9087 & 8,486687 & 34,1173889 \\
Y & 99 & $-0,5952$ & 6,1027 & 0,066895 & 0,6268753 \\
Valid N (listwise) & 99 & & & &
\end{tabular}

Berdasarkan hasil analisis statistik deskriptif terhadap ukuran perusahaan maka didapatkan hasil bahwa nilai minimum sebesar 4,6029 serta nilai maksimum sebesar 7,6457 dan nilai mean sebesar 6,187331 sedangkan nilai standar deviasi sebesar 0,7143145 .

Berdasarkan hasil analisis statistik deskriptif terhadap leverage maka didapatkan hasil bahwa nilai minimum sebesar 4,1224 serta nilai maksimum 
sebesar 106,8458 dan nilai mean sebesar 42,570372 sedangkan nilai standar deviasi sebesar 25,1292393.

Berdasarkan hasil analisis statistik deskriptif terhadap profitabilitas maka didapatkan hasil bahwa nilai minimum sebesar $-15,8412$ serta nilai maksimum sebesar 334,9087 dan nilai mean sebesar 8,486687 sedangkan nilai standar deviasi sebesar 34,1173889.

Berdasarkan hasil analisis statistik deskriptif terhadap manajemen laba maka didapatkan hasil bahwa nilai minimum sebesar -0,5952 serta nilai maksimum sebesar 6,1027 dan nilai mean sebesar 0,066895 sedangkan nilai standar deviasi sebesar 0,6268753.

Tabel 2.

Hasil Uji Koefisien Determinasi

\begin{tabular}{|c|c|c|c|c|}
\hline Model & $\mathrm{R}$ & R Square & Adjusted R Square & $\begin{array}{l}\text { Std. Error of the } \\
\text { Estimate }\end{array}$ \\
\hline 1 & $0,982^{\mathrm{a}}$ & 0,963 & 0,962 & 0,1224019 \\
\hline
\end{tabular}

Menunjukan hasil bahwa koefisien determinasi sebesar 0.962. Artinya 96,2\% asimetri informasi, ukuran perusahaan, leverage, profitabilitas mempengaruhi manajemen laba, sedangkan $(100 \%-96,2 \%=3,8 \%)$ dipengaruhi oleh faktor-faktor lain yang tdak masuk dalam persamaan regresi.

Uji F dilakukan untuk menguji kelayakan validitas dari suatu model regresi berganda.Dalam penelitian ini menggunakan program SPSS versi 23 dengan melihat nilai $\mathrm{F}$ yang ditampilkan. Hasil uji kelayakan model (Uji F) sebagai berikut

Tabel 3. 
Ni Putu Tia Rahma Yanti dan Putu Ery Setiawan. Pengaruh ...

\begin{tabular}{llrrrrr}
\hline Model & & Sum of Squares & df & Mean Square & F & Sig. \\
\hline 1 & Regression & 37,103 & 4 & 9,276 & 619,117 & $0,000^{\mathrm{b}}$ \\
& Residual & 1,408 & 94 & 0,015 & & \\
& Total & 38,511 & 98 & & & \\
\hline
\end{tabular}

Sumber: Data diolah, 2018

Berdasarkan hasil uji $\mathrm{F}$ didapatkan hasil bahwa nilai $\mathrm{F}$ memiliki tingkat signifikansi sebesar $0,000<0,05$. Hal tersebut berarti variabel asimetri informasi, ukuran perusahaan, leverage, dan profitabilitas secara simultan atau secara bersama-sama berpengaruh terhadap manajemen laba.

Uji t dilakukan untuk menguji pengaruh variabel independen terhadap manajemen laba secara parsial.Dalam penelitian ini pengujian dilakukan dengan menggunakan SPSS versi 23. Jika tingkat signifikansi $\leq \alpha=0,05$ maka $\mathrm{H}_{1}$ diterima dan Ho ditolak sedangkan jika tingkat signifikansi $>\alpha=0,05$ maka $\mathrm{H}_{1}$ ditolak dan Ho diterima. Hasil uji hipotesis dalam penelitian ini dapat dijelaskan pada Tabel 4 sebagai berikut :

Tabel 4.

Hasil Uji Hipotesis

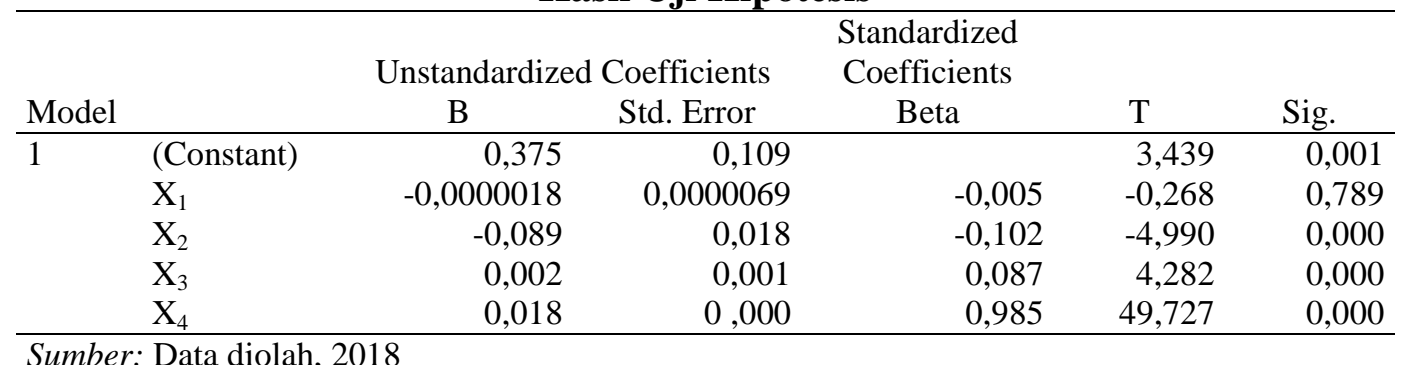

Dari hasil analisis yang telah dilakukan persamaan regresi yang didapat adalah sebagai berikut :

$$
Y=0,375-0,0000018 X_{1}-0,089 X_{2}+0,02 X_{3}+0,18 X_{4}+0,109
$$

Interpretasi yang dapat diuraikan berdasarkan persamaan regresi linier berganda diatas yaitu koefisien konstanya pada persamaan regresi sebesar 
0,375.Artinya, jika veriabel independen dianggap tidak ada maka manajemen laba sebesar bernilai positive sebesar 0,375 .

Koefisien regresi untuk variabel asimetri informasi $\left(\mathrm{X}_{1}\right)$ sebesar $-0,0000018$. Artinya, setiap ada kenaikan satu tingkatan terhadap variabel asimetri informasi dengan asumsi variabel lain tetap maka manajemen laba akan mengalami penurunan sebesar 0,0000018 .

Koefisien regresi untuk variabel ukuran perusahaan $\left(\mathrm{X}_{2}\right)$ sebesar $-0,089$. Artinya, setiap ada kenaikan satu tingkatan terhadap variabel ukuran perusahaan dengan asumsi variabel lain tetap maka manajemen laba akan mengalami penurunan sebesar 0,089 .

Koefisien regresi untuk variabel leverage $\left(\mathrm{X}_{3}\right)$ sebesar 0,02. Artinya, setiap ada kenaikan satu tingkatan terhadap variabel leverage dengan asumsi variabel lain tetap maka manajemen laba akan mengalami peningkatan sebesar 0,02.

Koefisien regresi untuk variabel profitabilitas $\left(\mathrm{X}_{4}\right)$ sebesar 0,18. Artinya, setiap ada kenaikan satu tingkatan terhadap variabel profitabilitas dengan asumsi variabel lain tetap maka manajemen laba akan mengalami peningkatan sebesar 0 , 18.

Berdasarkan Tabel 4hasil statistik menunjukan bahwa asimetri informasi $\left(\mathrm{X}_{1}\right)$ dengan nilai $\beta$ sebesar $-0,005$ dan tingkat signifikansi sebesar 0,789 lebih besar dari 0,05 . Hal ini menunjukkan $\mathrm{H}_{1}$ yang berbunyi asimetri informasi berpengaruh positif pada manajemen laba ditolak. Variabel ukuran perusahaan $\left(\mathrm{X}_{2}\right)$ dengan nilai $\beta$ sebesar $-0,102$ dan signifikansi ukuran perusahaan sebesar 0,000 lebih kecil dari 0,05 secara parsial berpengaruh negatif signifikan terhadap 
praktik manajemen laba. Hal ini menunjukkan $\mathrm{H}_{2}$ yang berbunyi ukuran perusahaan berpengaruh positif pada manajemen laba ditolak. Sedangkan variabel leverage $\left(\mathrm{X}_{3}\right)$ dengan nilai $\beta$ sebesar 0,087 dan memiliki tingkat signifikan 0,000 lebih kecil dari 0,05 Hal ini menunjukkan $\mathrm{H}_{3}$ yang berbunyi leverage berpengaruh positif pada manajemen laba diterima. Profitabilitas $\left(\mathrm{X}_{4}\right)$ dengan nilai $\beta$ sebesar0,985 dan memiliki tingkat signifikan 0,000 lebih kecil dari 0,05. Hal ini menunjukkan $\mathrm{H}_{4}$ yang berbunyi profitabilitas berpengaruh positif pada manajemen laba diterima

Berdasarkan hasil pengujian dengan uji statistik $t$ bahwa asimetri informasi tidak berpengaruh terhadap manajemen laba. Hal ini ditunjukkan dengan nilai signifikansi variabel asimetri informasi sebesar 0,789 lebih besar dari 0,05. Artinya, asimetri informasi secara empiris tidak mempengaruhi manajemen lana. Hasil penelitian ini memberikan kesimpulan bahwa $\mathrm{H}_{1}$ ditolak.Hal ini menandakan bahwa asimetri informasi bukanlah merupakan faktor yang sangat dipertimbangkan dalam tindakan manajemen laba yang dilakukan pihak manajemen perusahaan. Hasil penelitian ini bertentangan dengan penelitian Tobing (2005) dan Mayanda (2008) yang menyatakan bahwa asimetri infomasi berpengaruh signifikan positif terhadap manajemen laba.Semakin tinggi asimetri informasi yang terjadi antara principal dengan agent, maka semakin besar kemungkinan tindakan praktek manajemen laba yang dilakukan oleh agent didalam perusahaan. Hasil penelitian ini sejalan dengan penelitian yang dilakukan oleh Olyvia (2010), Miranti (2011) dan Siregar (2006) yang menyatakan bahwa asimetri informasi tidak berpengaruh terhadap manajemen laba dikrenakan jumlah sampel yng 
relatif tidak banyak sehingga pengukuran kurang tepat membuat asimetri nformasi tidak berpengaruh terhadap manajemen laba.

Beberapa hal yang menyebabkan asimetri informasi tidak berpengaruh signifikan, kemungkinan terjadi kesalahan pada pelaporan keuangan terdahulu yang tidak sesuai dengan kaidah kualitatif.Kaidah itu adalah pertama, laporan keuangan harus menyediakan informasi yang relevan dengan kebutuhan pemakainya atau dengan kata lain, laporan keuangan yang relevan adalah laporan keuangan yang dapat memenuhi kebutuhan informasi semua pihak yang membutuhkan.Kedua, laporan keuangan harus netral dari keinginan pihak-pihak tertentu yang ingin mengambil keuntungan pribadi dari informasi yang disajikan dalam laporan itu.Ketiga, laporan keuangan harus menyajikan informasi yang lengkap dan komprehensif, oleh sebab itu laporan keuangan harus mengungkapkan semua informasi mengenai kinerja dan kondisi perusahaan.Keempat, laporan keuangan harus mempunyai daya banding dan uji.Laporan keuangan dikatakan mempunyai daya banding apabila informasi yang disajikan dapat dibandingkan dengan informasi pada periode terdahulu atau perusahaan yang berbeda. Sedangkan daya uji adalah kemampuan laporan keuangan untuk tetap menghasilkan informasi yang sama apabila diuji kembali dengan menggunakan metode yang sama (Sulistyanto, 2008).

Berdasarkan hasil penelitian dengan uji statistik $\mathrm{t}$ bahwa ukuran perusahaan berpengaruh negatif signifikan terhadap praktik manajemen laba.Hal ini ditunjukan dengan nilai siginifikansi ukuran perusahaan sebesar 0,000. Artinya, ukuran perusahaan memiliki nilai signifikan lebih kecil dari 0,05. Secara empiris 
Ni Putu Tia Rahma Yanti dan Putu Ery Setiawan. Pengaruh ...

ukuran perusahaan berpengaruh negatif signifikan terhadap manajemen laba.Hasil penelitian ini memberikan kesimpulan bahwa $\mathrm{H}_{2}$ ditolak.

Semakin besar total aktiva perusahaan maka akan semakin besar ukuran perusahaan begitu juga sebaliknya. Perusahaan besar kurang memiliki dorongan untuk melakukan manajemen laba dibandingkan perusahaan-perusahaan kecil, karena perusahaan besar lebih banyak mendapat perhatian lebih oleh pemegang saham dan pihak luar.Perusahaan besar memiliki basis investor yang lebih besar, sehingga mendapat tekanan yang lebih kuat untuk menyajikan pelaporan keuangan yang kredibel. Maka, semakin besar ukuran perusahaan, akan menurunkan praktek manajemen laba yang dilakukan oleh manajemen.Peasnell, Pope, dan Young (1998) menunjukkan adanya hubungan negatif antara ukuran perusahaan dan manajemen laba di Inggris. Dengan ini disimpulkan bahwa manajer yang memimpin perusahaan yang lebih besar memiliki kesempatan yang lebih kecil dalam memanipulasi laba dibandingkan dengan manajer di perusahaan kecil.

Muliati (2011) menemukan bahwa ukuran perusahaan dengan manajemen laba berpengaruh negatif.Perusahaan besar kurang memiliki motivasi dalam melakukan praktik manajemen laba.Hal ini dikarenakan pemegang saham dan pihak-pihak yang berkepentingan di perusahaan besar dianggap lebih kritis dibandingkan dengan perusahaan kecil.Basis investor yang lebih besar terdapat pada perusahaan besar, sehingga perusahaan besar mendapat pressure yang lebih kuat untuk bisa menampilkan laporan keuangan yang dapat dipercaya (Marihot dan Setyawan, 2007). 
Berdasarkan hasil pengujian dengan uji statistik $t$ bahwa leverage berpengaruh signifikan terhadap manajemen laba. Hal ini ditunjukkan dengan nilai signifikansi variabel leverage sebesar 0,000 kurang dari taraf nyata 0,05 maka hipotesis pertama $\mathrm{H}_{3}$ diterima.Semakin tinggi leverage, maka semakin tinggi tingkat manajemen laba pada perusahaan manufaktur yang terdaftar di Bursa Efek Indonesia periode 2014-2016. Hasil penelitian ini sejalan dengan penelitian yang dilakukan oleh Yura (2015), Tarjo (2008), dan Tiya (2014) yang berpendapat bahwa leverage berpengaruh positif pada manajemen laba.

Perusahaan yang memiliki leverage tinggi akibat besarnya hutang dibandingkan aktiva yang dimiliki perusahaan, diduga melakukan manajemen laba karena perusahaan terancam default, yaitu tidak dapat memenuhi kewajiban membayar hutang pada waktunya. Keadaan ini mengindikasikan bahwa perusahaan dengan leverage tinggi memiliki pengawasan yang lemah terhadap manajemen yang menyebabkan manajemen dapat membuat keputusan sendiri, dan juga menetapkan strategi yang kurang tepat. Leverage yang tinggi disebabkan oleh kesalahan manajemen dalam mengolah keuangan perusahaan atau penerapan strategi yang kurang tepat dari pihak manajemen. Kurangnya pengawasan selain menyebabkan leverage yang tinggi juga akan meningkatkan perilaku oportunis manajemen salah satunya melakukan manajemen laba untuk mempertahankan kinerja manajemen di mata pemegang saham dan publik.

Berdasarkan hasil pengujian dengan uji statistik $\mathrm{t}$ bahwa profitabilitas berpengaruh signifikan terhadap manajemen laba. Hal ini ditunjukkan dengan nilai signifikansi variabel profitabilitas sebesar 0,000 kurang dari taraf nyata 0,05 
maka hipotesis pertama $\mathrm{H}_{4}$ diterima. Semakin tinggi profitabilias maka semakin meningkat manajemen laba yang terjadi, dan sebaliknya semakin rendah profitabilitas maka semakin rendah manajemen laba. Perusahaan yang mempunyai laba yang tinggi cenderung melaporkan labanya lebih kecildari laba sesungguhnya, karena perusahan yang memiliki laba yang tinggi menurut political cost perusahaan akan cenderung lebih diperhatikan oleh pemerintah dan masyarakat dibandingkan perusahaan yang memiliki laba yang kecil.

Profitabilitas merupakan kemampuan perusahan dalam mencari keuntungan atau laba.Laba yang dihasilkan perusahaan selama tahun berjalan dapat menjadi indicator terjadinya manajemen laba.Perusahan yang memiliki profitabilitas rendah cenderung melakukan manajemen laba dalam bentuk menaikkan laba, sedangkan perusahan yang memiliki profitabilitas tinggi cenderung melakukan manajemen laba dalam bentuk menurunkan laba. Pengaruh ini menunjukkan semakin rendah profitabilitas, maka akan semakin tinggi perusahaan melakukan manajemen laba. Semakin tinggi profitabilitas perusahaan, semakin rendah manajemen laba yang dilakukan perusahaan. Hasil penelitian ini di dukung penelitian sebelumnya yang dilakukan oleh Noviyanti (2014), Nasihah (2015), dan Alesia (2017) hasil penelitian mereka menunjukkan bahwa profitabilitas berpengaruh positif signifikan terhadap manajemen laba, artinya tanda positif adalah semakin tinggi profitabilitas semakin meningkat manajemen laba yang terjadi dan sebaliknya semakin rendah profitabilitas maka semakin rendah manajemen laba.

Implikasi penelitian ini mencangkup dua hal, yaitu implikasi teoritis dan 
implikasi praktis.Implikasi teoritis berkaitan dengan kontribusi terhadap perkembangan teori yang ada mengenai pengaruh asimetri informasi, ukuran perusahaan, leverage, dan profitabilitas terhadap manajemen laba perusahaan manufaktur.Implikasi praktis berkaitan dengan kontribusi penelitian terhadap pengaruh asimetri informasi, ukuran perusahaan, leverage, dan profitabilitas terhadap manajemen laba perusahaan manufaktur.

Penelitian ini diharapkan dapat menambah informasi dan pengetahuan mengenai pengaruh asimetri informasi, ukuran perusahaan, leverage, dan profitabilitas terhadap manajemen laba perusahaan manufaktur.Dalam penelitian ini walaupun hanya dua variabel yang berpengaruh terhadap manajemen laba yaitu variabel leverage, dan profitabilitas ada dua variabel yang tidak berdampak terhadap manajemen laba yaitu asimetri informasi, dan ukuran perusahaan.

Penelitian ini diharapkan dapat memberikan pertimbangan bagi investor bila ingin menanamkan modalnya pada suatu perusahaan agar investor tersebut tidak mendapat kerugian.Dan bagi manajer perusahaan dapat memikirkan kembali agar tidak melakukan kecurangan yang bisa mengakibatkan kerugian pada perusahaan itu sendiri.

\section{SIMPULAN}

Berdasarkan hasil pengujian dengan menggunakan analisis regresi linier berganda dapat ditarik kesimpulan bahwa asimetri informasi tidak berpengaruh terhadap manajemen laba. Hal ini ditunjukkan dengan nilai signifikansi asimetri informasi sebesar 0,789 lebih besar dari 0,05. Artinya, asimetri informasi secara empiris 
Ni Putu Tia Rahma Yanti dan Putu Ery Setiawan. Pengaruh ...

tidak mempengaruhi manajemen laba.Hasil penelitian ini memberikan kesimpulan bahwa hipotesis pertama ditolak.

Ukuran perusahaan yang diukur dengan log aktiva berpengaruh negatif terhadap manajemen laba. Hal ini ditunjukkan dengan nilai signifikansi ukuran perusahaan sebesar 0,000 . Artinya, ukuran perusahaan memiliki nilai signifikan lebih kecil dari 0,05. Secara empiris ukuran perusahaan berpengaruh negatif signifikan terhadap manajemen laba.Hasil penelitian ini memberikan kesimpulan bahwa hipotesis kedua ditolak.

Variabel leverage berpengaruh signifikan terhadap manajemen laba pada suatu perusahaan. Hal ini ditunjukkan dengan nilai signifikansi leverage sebesar 0,000. Artinya, leverage memiliki nilai signifikan lebih kecil dari 0,05. Secara empiris leverage berpengaruh terhadap manajemen laba. Hasil penelitian ini memberikan kesimpulan bahwa hipotesis ketiga diterima.

Variabel profitabilitas berpengaruh signifikan terhadap manajemen laba pada suatu perusahaan. Hal ini ditunjukkan dengan nilai signifikansi leverage sebesar 0,000. Artinya, profitabilitasmemiliki nilai signifikan lebih kecil dari 0,05. Secara empiris profitabilitas berpengaruh terhadap manajemen laba. Hasil penelitian ini memberikan kesimpulan bahwa hipotesis keempat diterima.

Agar hasil penelitian yang didapat bisa digunakan secara umum dan luas sebaiknya peneliti selanjutnya dapat menggunakan seluruh perusahaan yang terdaftar di Bursa Efek Indonesia.

Penelitian selanjutnya disarankan untuk meneliti lebih dalam mengenai faktor-faktor yang dapat mempengaruhi manajemen laba dengan menggunakan 
variabel independen yang berbeda, seperti menggunakan variable goodcorporate governance yang secara teori diharapkan dapat mengurangi penerapan manajemen laba atau peneliti dapat memilih variabel lain yang diperkirakan berhubungan dengan praktik manajemen laba tersebut.

Untuk mendapatkan hasil yang lebih akurat sebaiknya penelitian selanjutnya menggunakan metode penelitian yang berbeda dan menggunakan proksi yang berbeda untuk mengukur ukuran perusahaan.

\section{REFERENSI}

Beneish, M. D. (2001). Earnings management: a perspective. Managerial Finance, 27(12), 3-17.

Chen, Li-Ju dan Shun Yu Chen (2011). The Influence of Profitability on Firm Value With Capital Structure as The Mediator and Firm Size and Industry as Moderators, Investment Management and Financial Inovations PP : 121129

Cristie and Zimmerman.J.1994. "Efficient and Opportunistic Choices of Accounting Procedures : Corporate Control Contest". The Accounting Review Vol 69 No. 4

Chtourou, Sonda Marrakchi, Jean Bedard, and Lucie Courteau. (2001). "Corporate Governance and Earnings Management". https://papers.ssrn.com

Desmiyawati.2009, Pengaruh Asimetri Informasi dan Ukuran Perusahaan terhadap Manajemen Laba pada Perusahaan Manufaktur yang Terdaftar di Bursa Efek Indonesia.Pekbis Jurnal, 1(3). H: 180-189

Dewi, Made Yustiari dan Sujana, I Ketut.2014. Pengaruh Ukuran Perusahaan dan Profitabilitas Pada Praktik Perataan Laba dengan Jenis Industri Sebagai Variabel Pemoderasi di Bursa Efek Indonesia.E-Journal Akuntansi Universitas Udayana.

Dewi, Lindira Sukma dan Ulupui.2014. Pengaruh Pajak Penghasilan dan Aset Perusahaan pada Earning Management.Fakultas Ekonomi dan Bisnis 
Universitas Udayana, Bali.E-Jurnal Akuntansi Universitas Udayana.Vol 8.1.HIm250-259. 2014

Firdaus, Rachmat. 2003. Manajemen Perkreditan Bank Umum. Penerbit Alfabet. Bandung

Firdaus, Ilham. 2013, Pengaruh Asimetri Informasi dan Capital Adequacy Ratio terhadap Manajemen Laba.Skipsi.Universitas Negeri Padang

Healy, P.M., \& J.M. Wahlen. 1999. A Review of the Earnings Management Literature and Its Implications for Standard Setting, Accounting Horizon, 13: h: 365-383

Herawati, Nuruldan Baridwan. 2007. Manajemen Laba Pada Perusahaan Yang Melanggar Perjanjian Utang.Simposium Nasional Akuntansi X Makasar.

Herni dan Yulius Kurnia Susanto. 2008. Pengaruh Struktur Kepemilikan Publik, Praktik Pengelolaan Perusahaan, Jenis Industri, Ukuran Perusahaan, Profitabilitas dan Risiko Keuangan terhadap Tindakan Perataan Laba (Studi Empiris pada Industri yang Listing di Bursa Efek Jakarta). Jurnal Ekonomi danBisnis Indonesia. Vol. 23 No.3

Jao, Robert dan Pagalung, Gagaring. "Corporate Governance, Ukuran Perusahaan, dan Leverage Terhadap Manajemen Laba Perusahaan Manufaktur Indonesia”. Jurnal Akuntansi \& Auditing Vol 8 No. 1.2011

Jones, J.J. 1991. Earnings management during import relief investigations. Journal of Accounting Research 29(2): h:193-228.

Juniarti dan Carolina. 2005. "Analisa Faktor-Faktor yang Berpengaruh Terhadap Perataan Laba (Income Smoothing) Pada Perusahaan-Perusahaan Go Public". Jurnal Akuntansi \& Keuangan.Vol. 7 No. 2.Nopember.hal: 148162.

Kim et al. 2003.The Effect of Firm Size on Earnings management: Social Science Research Network Elerctric. Paper Collection.

Moses, Douglas O, 1997, Income Smootingand Incentives: Empirical Using Accounting Changes. The Accounting Review, Vol. LXII, No.2, April, pp. 259-377

Makaombohe, Y.Y, Sifrid S.P, dan Victorina Z.T. "Ukuran Perusahaan Terhadap Manajemen Laba Pada Perbankan yang Terdaftar di Bursa Efek Indonesia Periode 2008-2011".Jurnal EMBA Vol. 2 No. 1.2014. 
Mardiyah, Listianingsih. 2005. Pengaruh Sistem Pengukuran Kinerja, Sistem Reward dan Profit Center terhadap Hubungan Antara Total Quality Manajemen dengan Kinerja Manajerial, Simposium Nasional Akuntansi VII, Solo.

Miranti, Senja. 2011. Pengaruh Asimetri Informasi dan Ukuran Perusahaan Terhadap Manajemen Laba pada Perusahaan yang Go Public di BEI.Skripsi. Padang: Universitas Negeri Padang.

Muliati, Ni Ketut. "Pengaruh Asimetri Informasi dan Ukuran Perusahaan Pada Praktik Manajemen Laba di Perusahaan Perbankan yang Terdapad di Bursa Efek Indonesia”.Tesis.Program Magister Universitas Udayana Denpasar, 2011.

Nufus, Nurhayatun. 2009. Analisis Pengaruh Ukuran Perusahaan, Profitibilitas, dan Financial LeverageTerhadap Tindakan Income Smoothing pada Perusahaan Sektor Keuangan (Finance) yang Terdaftar di BEI Periode 2004-2008. Skripsi. Fakultas Ekonomi Universitas Gunadarma, Jakarta.

Olyvia, Angella. 2010. Pengaruh Asimetri informasi dan Nilai Earning Per Share (EPS) Terhadap Praktik Manajemen Laba pada Perusahaan Manufaktur di BEI. Skripsi.Universitas Negeri Padang

Othman, B.H., Zhegal, D. 2006. A Study of Earnings Management Motives in the Anglo-American and Euro-Continental Accounting Models: the Canadian and French Cases. The International Journal of Accounting, 41, 406-435.

Peasnell, KV., PF Pope, and S Young. 1998. Outside Director, Board Effectiveness, and Earning Management. Working Papers from Lancaster University

Prempanichnukul, Varaporn, dan Krittaya Sangboon. 2012. The Effect Of Managerial Ownership On Earnings Quality. Journal of International Finance \& Economics. 12(4): h: 5-16.

Purwantini, V. T., 2011, Pengaruh Mekanisme Good Corporate Governance terhadap Nilai Perusahaan dan Kinerja Keuangan Perusahaan yang terdaftar di Bursa Efek Indonesia, Jurnal Ekonomi Bisnis dan Perbankan, 19.

Prambudi, E. Januar dan Sumantri, A. Farid. "Kualitas Audit, Ukuran Perusahaan, dan Leverage Terhadap Manajemen Laba". SNA XVII Mataram. 2014. 
Rice dan Agustina, 2012. Analisa Faktor-faktor yang Mempengaruhi Tindakan Manajemen Laba Pada Perusahaan Indeks Kompas 100 yang Terdaftar Di Bursa Efek Indonesia.

Riyanto, Bambang, “Dasar-dasar Pembelanjaan Perusahaan”, Yogyakarta, BFE UGM. 2001.

Rahmawati, Yacop Suparno dan Nurul Qomariyah.2006.Pengaruh Asimetri Informasi Terhadap Praktek Manajemen Laba pada Perusahaan Perbankan Publik yang Terdaftar di Bursa Efek Jakarta.Simposium Nasional Akuntansi 9 (Padang).

Richardson, V.J., 1998, Information Asymetry and Earnings Management : Some Evidence, Retrieved March3 ${ }^{\text {rd }}, 2007$

Saptantinah Dewi, 2007. Analisis Faktor-faktor yang Mempengaruhi Motivasi Manajemen Laba Di Seputar Right Issue. Jurnal fakultas Ekonomi, Universitas Udayana, Denpasar

Schiff and Lewin, 1970.The Impact of People on Budgets. The Accounting Review. April. Pp. 259-268

Siregar, Sylvia Veronica N. P. dan Yanivi S. Bachtiar, 2003, " Hubungan antaraManajemen Laba dengan Tingkat Pengungkapan Laporan Keuangan, "Simposium Nasional Akuntansi VI.

Siregar dan Utama. "Pengaruh Struktur Kepemilikan, Ukuran Perusahaan, dan Praktek Corporate Governance Terhadap Pengelolaan Laba (Earnings Management)". SNA VIII Solo. 2005.

Sulistyanto, Sri. "Manajemen Laba: Teori dan Model Empiris". PT. Gramedia Widiasarana Indonesia. Jakarta. 2008.

VAN Horne, B. (1997). Response of Deer Mice (Peromyscus maniculatus) to shrubs in shortgrass prairie: linking small-scale movements and the spatial distribution of individuals. Functional Ecology, 11(1991), 644-651.

Veronica, Sylvia N.P Siregar dan Siddharta Utama.2005. Pengaruh Struktur Kepemilikan, Kepemilikan institusional, dan Praktek Corporate Governance Terhadap Pengelolaan Laba (Earning Management).Simposium Nasional Akuntansi 8.(Solo)

Watts, Ross L and Jerold Zimmerman, 1986. Positive Accounting Theory. Prentice Hall International Inc. New Jersey. 
Wibisana, Imas Danar dan Ratnaningsih, Dewi.“Analisis Faktor-Faktor yang Mempengaruhi Arah Manajemen Laba Studi Pada Perusahaan Manufaktur yang Terdaftar di BEI 200-2013" E-Journal Universitas Atma Jaya Yogyakarta. 2014.

Zhou, Jian and Lobo, Gerald J. "Disclosure Quality and Earning Management. Asia-Pasific Journal of Accounting and Economics, Vol. 8 No. 1 pp: 1-20, 2001 